\title{
MENGUJI NIAT TURIS UNTUK MELAKUKAN PERJALANAN WISATA PASCA PANDEMI COVID-19
}

\author{
Afif Khairi, Usep Suhud, Osly Usman \\ Universitas Negeri Jakarta (UNJ) Indonesia \\ Email: afkhai5@gmail.com,usuhud@unj.ac.id,oslyusman@unj.ac.id
}

\begin{abstract}
Abstrak
Tujuan dari penelitian ini adalah menguji faktor-faktor yang memengaruhi variabel niat berkunjung dengan menggunakan persepsi risiko, persepsi nilai, motivasi perjalanan, citra destinasi sebagai prediktor. Metode pengumpulan data menggunakan metode survei. Objek penelitian ini adalah 201 responden yang berniat untuk melakukan perjalanan ke luar negeri pasca pandemi covid-19 dan sudah pernah melakukan perjalanan ke luar negeri minimal 1 kali. Analisis data menggunakan SPPS versi 19 dan SEM (Structural Equation Modeling) AMOS versi 22. Nilai fit model dengan $P$ sebesar 0.053, nilai CMIN/DF sebesar 1.178, nilai TLI sebesar 0.983 CFI sebesar 0.985 dan nilai RMSEA sebesar 0.030 .
\end{abstract}

Kata Kunci: persepsi risiko; motivasi perjalanan; persepsi nilai; citra destinasi; niat berkunjung

\section{Abstract}

The purpose of this study is to examine the factors that influence the variables of visit intention by using perceived risk, perceived value, travel motivation, destination image as a predictor. Methods of data collection using the survey method. The object of this research was 201 respondents who wants to travel abroad after the covid-19 pandemic. The data analysis using SPSS version 19 and SEM (Structural Equation Modeling) AMOS version 22. Fit model value with $P$ of 0.053, CMIN/DF of 1.178, TLI of 0.983, CFI of 0.985 and RMSEA of 0.030.

Keywords: perceived risk; perceived value; travel motivation; destination image; visit intention

Received: 2021-12-20; Accepted: 2022-01-05; Published: 2022-01-15

\section{Pendahuluan}

Pada awal Desember 2019, Komisi Kesehatan di Kota Wuhan, Tiongkok/ Wuhan Municipal Health Commission (WMHC) melaporkan adanya 27 kasus pneumonia yang viral dan 7 diantara pasien tersebut dikategorikan mempunyai penyakit yang sangat serius. Kesemua pasien tersebut diyakini pernah mengunjungi dan terpapar di sebuah pasar yang menjual hewan ternak, kelelawar dan ular yaitu pasar Huanan Seafood Wholesale Market disinilah diduga awal mula kemunculan virus yang sekarang kita

How to cite:

E-ISSN:

Published by:
Khairi. A., Usep Suhud \& Osly Usman (2022) Menguji Niat Turis Untuk Melakukan Perjalanan Wisata Pasca Pandemi Covid-19. Syntax Literate: Jurnal Ilmiah Indonesia, 7(1). http://dx.doi.org/10.36418/syntax-literate.v7i1.5877 $2548-1398$

Ridwan Institute 
kenal sebagai coronavirus infectious disease (covid-19) (Lloveras, S., RodriguezMorales, A. J., \& Schlagenhauf, 2020).

Sementara itu di Indonesia sendiri kasus pertama adanya virus corona terjadi pada tanggal 2 Maret 2020, terkonfirmasi ada 2 orang WNI yang terinfeksi virus ini. Pada tanggal 11 Maret 2020 Indonesia mengumumkan kasus kematian pertama akibat virus corona yaitu pasien kasus nomor 25, seorang WNA yang menjalani perawatan di RS Sanglah, Denpasar, Bali. Di tanggal yang sama World Health Organization (WHO) menyatakan wabah virus corona dinyatakan sebagai pandemi saat Turki, Pantai Gading, Honduras dan Bolivia mengkonfirmasi kasus pertama di wilayahnya (Tamtomo, 2020).

Di Indonesia, penurunan disektor pariwisata sudah terasa dampaknya. Industri ini diklaim menanggung kerugian setidaknya US\$1,5 miliar atau setara Rp. 21 triliun sejak Januari 2020 akibat pandemi covid-19. Angka tersebut terdiri dari risiko kerugian akibat kehilangan pendapatan dari turis China senilai US $\$ 1,1$ miliar dan sisanya US $\$ 400$ juta dengan nilai kerugian dari wisatawan asal negara lain. Sejak pandemi covid-19 ini merebak, tingkat hunian kamar hotel dengan klasifikasi hotel berbintang rata-rata hanya menembus 49,2 persen. Sedangkan disektor penerbangan, dampak covid-19 menyebabkan kehilangan pendapatan senilai Rp. 207 miliar. sepanjang Januari sampai dengan Februari 2020 sebanyak 12.703 penerbangan di 15 bandara dibatalkan. Jika dirincikan, sebanyak 11.680 merupakan penerbangan domestik dan 1.023 merupakan penerbangan internasional (Herlinda, 2020).

Berdasarkan data dari situs kemenparkeraf.go.id pada Jumat, 2 Oktober 2020 kunjungan wisman ke Indonesia melalui seluruh pintu masuk bulan Agustus 2020 berjumlah 164.970 kunjungan atau mengalami penurunan sebesar $-89,22 \%$ dibandingkan bulan Agustus 2019 yang berjumlah 1.530.268 kunjungan. Kunjungan wisman pada 3 (tiga) pintu besar dari 26 pintu masuk utama bulan Agustus 2020 dibandingkan bulan Agustus 2019, yaitu: Ngurah Rai mengalami penurunan sebesar $100 \%$; Soekarno-Hatta mengalami penurunan sebesar $-98,22 \%$; serta Batam mengalami penurunan sebesar $-99,92 \%$. Berdasarkan kebangsaan, jumlah kunjungan wisman bulan Agustus 2020 di seluruh pintu masuk tercatat jumlah kunjungan tertinggi, yaitu: Timor Leste sejumlah 88.408 kunjungan, Malaysia sejumlah 58.291 kunjungan, Tiongkok sejumlah 3.655 kunjungan, Amerika Serikat sejumlah 1.768 kunjungan, dan Belanda sejumlah 1.367 kunjungan.

Pada bulan februari tercatat ada 863.960 kunjungan terjadi penurunan sebanyak 380036 dibandingkan dengan tahun sebelumnya, pada bulan maret 2019 tercatat ada 470.970 kunjungan terjadi penurunan yang sangat signifikan yaitu sebanyak 840.941. Ini disebabkan karena semakin merebaknya wabah covid-19 di Indonesia, maka dari itu para wisatawan mancanegara menahan diri untuk berwisata ke Indonesia.

Sementara itu jika melihat jumlah wisatawan Indonesia yang bepergian ke luar negeri menurut data Bank Indonesia menyebut selama tahun 2016 jumlah warga negara Indonesia yang ke luar negeri mencapai 8,4 juta orang dan ada 9 juta orang Indonesia yang bepergian ke luar negeri sepanjang 2017 dan diperkirakan pertumbuhannya sekitar 20 persen per tahun, sehingga diperkirakan jumlah orang Indonesia yang melakukan 
kunjungan atau berwisata keluar negeri (outbound) pada 2020 bisa mencapai 12 juta orang (Sirait, 2020).

Dikarenakan adanya pandemi covid-19 pertumbuhan yang akan terjadi sekitar 20 persen atau kunjungan wisatawan Indonesia yang berwisata keluar negeri bisa mencapai 12 juta orang akan sulit dicapai pada tahun ini dan tahun depan sampai vaksin covid-19 ditemukan dan pandemi covid-19 dinyatakan telah berakhir. Menurut Google Consumer Survey, minat masyarakat Indonesia untuk keluar negeri masih cukup tinggi. Terdapat 44 persen masyarakat Indonesia yang ingin melakukan perjalanan keluar negeri dalam rentang waktu satu tahun kedepan. Terdapat 17 persen masyarakat Indonesia ingin melakukan perjalanan ke luar negeri dalam rentang waktu tiga bulan kedepan dan sisanya ingin melakukan perjalanan dalam jangka waktu enam bulan kedepan (Ridhoo Maulaa, 2020).

Jika melihat dari situasi seperti yang dikemukakan diatas apakah masih ada orang Indonesia yang ingin melakukan perjalanan wisata ke luar negeri setelah pandemi ini berakhir? Apakah sektor pariwisata masih menguntungkan dan menjadi salah satu prioritas orang Indonesia setelah pandemi ini berakhir? Peneliti mencoba untuk memahami dan menganalisis faktor-faktor apa saja yang bisa memengaruhi calon wisatawan dari Indonesia untuk melakukan perjalanan wisata ke luar negeri setelah pandemi covid-19 berakhir.

Persepsi risiko didefinisikan sebagai persepsi konsumen tentang ketidakpastian dan konsekuensi negatif dari pembelian suatu barang dan jasa dalam melakukan aktivitas tertentu. Persepsi risiko didefinisikan sebagai persepsi konsumen terhadap probabilitas bahwa suatu tindakan dapat membuat mereka terancam bahaya yang dapat memengaruhi keputusan pembelian/perjalanan jika bahaya yang dirasakan dianggap melampaui batas (Chew \& Jahari, 2014).

Menurut (Cheng, Kuo, Chang, \& Chen, 2019) perceived value adalah penilaian keseluruhan dari pengunjung atas pengeluaran bersih selama perjalanan, berdasarkan penilaian pengunjung tentang apa yang diterima (manfaat), dan apa yang diberikan (biaya atau pengorbanan). Dalam istilah sederhana, ini adalah evaluasi keseluruhan dari manfaat dan biaya dari perspektif pengunjung.

Menurut Pearce (Soliman, 2021) travel motivation atau motivasi perjalanan adalah bagian tertentu dari motivasi individu yang mencakup keseluruhan jaringan biologis dan kekuatan budaya yang memberikan nilai dan tren untuk pilihan perjalanan, perilaku dan pengalaman. Secara umum, keputusan turis untuk mengunjungi suatu tujuan tertentu dapat dikaitkan dengan dua kategori motivasi yatu faktor "pendorong" dan "penarik" atau push and pull factors (Nassar, Mostafa, \& Reisinger, 2015).

Citra destinasi adalah seperangkat ide dan keyakinan bahwa seseorang memiliki kesan terhadap suatu tempat ataupun tujuan (Carla, Andajani, \& Rahayu, 2017). Menurut (Nassar et al., 2015) konsep destination image mengacu pada ide dari tujuan yang dibuat dalam pikiran wisatawan, biasanya representasi mental atau seperangkat atribut atau sebuah persepsi yang ada dalam memori traveler. Menurut (Khan, Chelliah, \& Ahmed, 2017) destination image mengacu pada ide, keyakinan dan kesan yang 
diperoleh individu tentang karakteristik serta aktivitas di sebuah tujuan setelah menganalisis informasi yang dikumpulkan dari berbagai sumber kurun waktu tertentu.

Menurut (Hashim, Noor, Awang, Aziz, \& Yusoff, 2018) dalam konteks tourism marketing, visit intention atau niat untuk berkunjung mengacu pada persepsi sesorang yang kemungkinan mengunjungi tempat tertentu dalam periode tertentu. Sedangkan menurut (Yacob, Johannes, \& Qomariyah, 2019) niat dalam konsep pemasaran pariwisata adalah kecenderungan individu untuk tertarik pada suatu objek atau senang pada suatu tempat/destinasi. Di dunia penelitian, niat berarti kemauan wisatawan terhadap obyek-obyek wisata yang ditawarkan oleh pengelola destinasi wisata sebagai tempat pariwisata. Menurut (Suwarduki, Yulianto, \& Mawardi, 2016) niat berkunjung pada dasarnya adalah dorongan dari dalam diri sendiri, berupa keinginan untuk mengunjungi suatu tempat yang menarik perhatian.

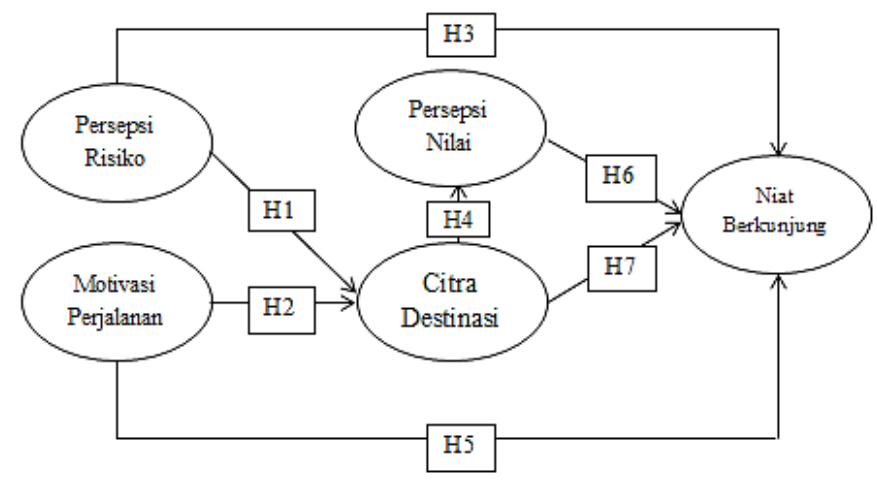

Gambar 1

Model Penelitian

Dari gambar di atas, maka dikemukakan hipotesis sebagai berikut:

$\mathrm{H}_{1}$ : Terdapat pengaruh positif dan signifikan dari persepsi risiko terhadap citra destinasi.

$\mathrm{H}_{2}$ : Terdapat pengaruh positif dan signifikan dari motivasi perjalanan terhadap citra destinasi.

$\mathrm{H}_{3}$ : Terdapat pengaruh positif dan signifikan dari persepsi risiko terhadap niat berkunjung.

$\mathrm{H}_{4}$ : Terdapat pengaruh positif dan signifikan dari citra destinasi terhadap persepsi nilai.

$\mathrm{H}_{5}$ : Terdapat pengaruh positif dan signifikan dari motivasi perjalanan terhadap niat berkunjung.

$\mathrm{H}_{6}$ : Terdapat pengaruh positif dan signifikan dari persepsi nilai terhadap niat berkunjung.

$\mathrm{H}_{7}$ : Terdapat pengaruh positif dan signifikan dari citra destinasi terhadap niat berkunjung. 


\section{Metode Penelitian}

Metode pengumpulan data menggunakan metode survey yaitu dengan penyebaran kuesioner yang telah terstuktur yang diberikan kepada responden yang dirancang untuk mendapatkan informasi yang lebih spesifik. Berdasarkan dimensi waktu, penelitian ini menggunakan studi lintas-seksi (cross-sectional). Studi cross-sectional meliputi pengumpulan data mengenai sampel yang telah ditentukan dari elemen populasi hanya satu kali.

Populasi pada penelitian ini adalah calon wisatawan dalam negeri yang ingin berkunjung/berlibur ke luar negeri pasca pandemi covid-19. Jenis populasi yang akan diteliti adalah populasi infinite, yaitu objek dengan ukuran yang tidak terhingga yang karakteristiknya dikaji atau diuji melalui sampling karena peneliti tidak mengetahui jumlah pasti calon wisatawan dalam negeri yang ingin berkunjung/berlibur ke luar negeri pasca pandemi covid-19.

Dalam penelitian ini menggunakan metode purposive sampling. Metode purposive sampling dalam penelitian ini adalah calon wisatawan yang ingin berkunjung/berlibur ke luar negeri pasca pandemi covid-19 dan sudah melakukan perjalanan ke luar negeri minimal 1 kali perjalanan. Alasan ditetapkan batasan tersebut ialah diharapkan kriteria sampel yang akan diambil benar-benar memenuhi kriteria yang sesuai dengan penelitian yang akan dilakukan. Maka pengambilan sampel yang akan digunakan dalam penelitian ini akan disesuaikan berdasarkan pada poin pertama ketentuan ukuran sampel $100-200$ untuk teknik estimasi maximum likehood $(M L)$, hal ini telah memenuhi kriteria jumlah minimal sampel. Berdasarkan kajian penelitian terdahulu dapat dilihat bahwa mereka juga menggunakan sampel yang berkisar antara 100-300 sehingga peneliti akan menggunakan sampel yaitu dengan jumlah 201 sampel.

Dalam penelitian ini digunakan dua sumber data antara lain data primer dan data sekunder. Data primer dalam penelitian ini dikumpulkan dengan menggunakan kuisioner yang diberikan secara langsung kepada responden untuk memperoleh informasi tentang variabel-variabel yang diteliti dalam penelitian ini. Data ini dikumpulkan sendiri oleh peneliti melalui pembagian kuesioner kepada 201 orang responden yang ingin berlibur ke luar negeri pasca pandemi covid-19. Data sekunder dalam penelitian ini berasal dari beberapa portal berita dan situs lainnya yang digunakan dalam pencarian referensi teori maupun jurnal. Metode yang digunakan untuk pengumpulan data pada penelitian ini adalah metode survei dan metode observasi pada objek calon wisatawan yang ingin berkunjung/berlibur ke luar negeri pasca pandemi covid-19 berakhir. 


\section{Hasil dan Pembahasan}

\section{A. Analisis Faktor Eksploratori}

\section{Persepsi Risiko}

\section{Tabel 1}

Faktor Analisis Persepsi Risiko

\begin{tabular}{|c|c|c|c|}
\hline \multirow{2}{*}{ Nama } & \multirow{2}{*}{ Pernyataan } & \multicolumn{2}{|c|}{ Factor Loading } \\
\hline & & 1 & 2 \\
\hline PR14 & $\begin{array}{l}\text { Saya merasa bahwa saya tidak akan menerima } \\
\text { kepuasan pribadi yang cukup dari liburan ke luar } \\
\text { negeri }\end{array}$ & 0,834 & \\
\hline PR13 & $\begin{array}{l}\text { Saya merasakan risiko serangan teroris saat berlibur ke } \\
\text { luar negeri }\end{array}$ & 0,808 & \\
\hline PR6 & $\begin{array}{l}\text { Merencanakan dan mempersiapkan perjalanan ke luar } \\
\text { negeri akan memakan waktu saya terlalu banyak }\end{array}$ & 0,788 & \\
\hline PR4 & $\begin{array}{l}\text { Saya merasakan trauma psikologis karena komentar } \\
\text { negatif orang lain tentang destinasi yang akan saya } \\
\text { tuju }\end{array}$ & 0,775 & \\
\hline PR15 & $\begin{array}{l}\text { Bepergian ke luar negeri tidak akan cocok dengan } \\
\text { image saya }\end{array}$ & 0,77 & \\
\hline PR5 & $\begin{array}{l}\text { Bepergian ke luar negeri akan membuang-buang waktu } \\
\text { saya }\end{array}$ & 0,72 & \\
\hline PR7 & $\begin{array}{l}\text { Saya merasa ada kemungkinan bahaya fisik bagi } \\
\text { kesehatan saya saat berlibur ke luar negeri }\end{array}$ & 0,616 & \\
\hline PR3 & $\begin{array}{l}\text { Saya merasakan ancaman jatuh sakit saat bepergian ke } \\
\text { luar negeri atau berada di tempat tujuan }\end{array}$ & 0,568 & \\
\hline PR11 & $\begin{array}{l}\text { Saya merasa bahwa saya mungkin terjebak dalam } \\
\text { kekacauan politik saat berlibur ke luar negeri }\end{array}$ & 0,557 & \\
\hline PR8 & $\begin{array}{l}\text { Keamanan pangan di luar negeri sangat } \\
\text { mengkhawatirkan bagi saya }\end{array}$ & 0,508 & \\
\hline Cronbach's Alpha & & $\mathbf{0 , 9 0 3}$ & \\
\hline PR10 & $\begin{array}{l}\text { Tingkat kejahatan seperti (pencurian, perampokan, } \\
\text { pencopet) di luar negeri akan sangat berpengaruh pada } \\
\text { keputusan saya }\end{array}$ & & 0,766 \\
\hline PR9 & $\begin{array}{l}\text { Masih adanya kasus covid-19 di negara tersebut akan } \\
\text { sangat berpengaruh pada keputusan saya }\end{array}$ & & 0,742 \\
\hline PR2 & $\begin{array}{l}\text { Melakukan perjalanan ke luar negeri pasti akan } \\
\text { mengalami pengel } \\
\text { uaran tambahan yang tidak terduga (seperti perubahan } \\
\text { nilai tukar, biaya tambahan di hotel) }\end{array}$ & & 0,723 \\
\hline PR12 & $\begin{array}{l}\text { Saya menghadapi hambatan bahasa saat berlibur ke } \\
\text { luar negeri }\end{array}$ & & 0,467 \\
\hline Cronbach's Alpha & & & 0,684 \\
\hline
\end{tabular}

Sumber: Data diolah peneliti (2020)

Dari tujuh belas pernyataan kuesioner, variabel persepsi risiko tersisa empat belas pernyataan yang dapat difaktorkan pernyataan yang lainnya dieliminasi karena adanya cross-factor, hasil faktor analisis ini membentuk dua faktor dimensi. 


\section{Persepsi Nilai}

Tabel 2

Faktor Analisis Persepsi Nilai

\begin{tabular}{|c|c|c|}
\hline Nama & Pernyataan & $\begin{array}{c}\text { Factor } \\
\text { Loading } \\
1\end{array}$ \\
\hline PV10 & $\begin{array}{l}\text { Saya merasakan manfaat perjalanan sesuai dengan harga } \\
\text { yang saya bayarkan }\end{array}$ & 0,849 \\
\hline PV1 & $\begin{array}{l}\text { Objek wisata di luar negeri memberikan kesan yang baik } \\
\text { bagi saya }\end{array}$ & 0,829 \\
\hline PV8 & $\begin{array}{l}\text { Harga yang saya bayar untuk mendapatkan objek wisata } \\
\text { yang menyenangkan di luar negeri cukup wajar }\end{array}$ & 0,814 \\
\hline PV7 & $\begin{array}{l}\text { Saya mendapatkan layanan yang setimpal dengan uang } \\
\text { yang sudah saya keluarkan di objek wisata yang saya } \\
\text { kunjungi }\end{array}$ & 0,801 \\
\hline PV3 & $\begin{array}{l}\text { Saya merasa mendapat pengetahuan tambahan melalui } \\
\text { perjalanan ke luar negeri }\end{array}$ & 0,791 \\
\hline PV2 & $\begin{array}{l}\text { Saya merasa senang mengunjungi objek wisata yang telah } \\
\text { saya pilih di luar negeri }\end{array}$ & 0,784 \\
\hline PV4 & $\begin{array}{l}\text { Saya merasa mendapatkan pengalaman yang tak terlupakan } \\
\text { selama perjalanan saya di luar negeri }\end{array}$ & 0,775 \\
\hline PV9 & $\begin{array}{l}\text { Saya mengunjungi objek wisata sesuai dengan harga yang } \\
\text { saya bayarkan pada paket wisata }\end{array}$ & 0,716 \\
\hline PV5 & $\begin{array}{l}\text { Saya merasa objek wisata di luar negeri unik dan tidak } \\
\text { dimiliki oleh objek wisata di dalam negeri }\end{array}$ & 0,658 \\
\hline PV6 & $\begin{array}{l}\text { Saya mendapatkan pengalaman berharga di luar negeri dan } \\
\text { saya akan menceritakannya }\end{array}$ & 0,629 \\
\hline $\begin{array}{c}\text { Cronbach's } \\
\text { Alpha }\end{array}$ & & 0,914 \\
\hline
\end{tabular}

Sumber: Data diolah peneliti (2020)

Dari sepuluh pernyataan kuesioner, variabel persepsi nilai semua pernyataan dapat difaktorkan dam tidak ada penyataan yang dieliminasi.

\section{Motivasi Perjalanan}

Tabel 3

Faktor Analisis Motivasi Perjalanan

\begin{tabular}{clllll}
\hline \multirow{2}{*}{ Nama } & \multicolumn{1}{c}{ Pernyataan } & \multicolumn{4}{c}{ Factor Loading } \\
\cline { 2 - 5 } TM7 & $\begin{array}{l}\text { Tujuan saya ke luar negeri adalah } \\
\text { ingin mengunjungi destinasi } \\
\text { wisata yang akan membuat } \\
\text { teman-teman saya kagum } \\
\text { terhadap saya }\end{array}$ & & & & \\
\hline \multirow{2}{*}{ TM6 } & $\begin{array}{l}\text { Tujuan saya ke luar negeri adalah } \\
\text { ingin menjadi terkenal }\end{array}$ & 0,923 & & \\
\hline TM8 & $\begin{array}{l}\text { Saya ingin membuat orang-orang } \\
\text { hormat kepada saya }\end{array}$ & 0,876 & \\
\hline TM5 & Tujuan saya ke luar negeri adalah & 0,599 & \\
\hline
\end{tabular}




\begin{tabular}{|c|c|c|c|c|c|c|}
\hline & $\begin{array}{l}\text { ingin ke tempat dimana teman- } \\
\text { teman saya belum pernah } \\
\text { kunjungi }\end{array}$ & & & & & \\
\hline TM18 & $\begin{array}{l}\text { Tujuan saya ke luar negeri adalah } \\
\text { ingin mengunjungi kasino dan } \\
\text { bermain game }\end{array}$ & 0,502 & & & & \\
\hline TM16 & $\begin{array}{l}\text { Tujuan saya ke luar negeri adalah } \\
\text { ingin melihat selebriti, seperti } \\
\text { bintang olahraga dan bintang film }\end{array}$ & 0,491 & & & & \\
\hline $\begin{array}{l}\text { Cronbach's } \\
\text { Alpha }\end{array}$ & & $\mathbf{0 , 8 8 4}$ & & & & \\
\hline TM2 & $\begin{array}{l}\text { Tujuan saya ke luar negeri adalah } \\
\text { ingin beristirahat sejenak dari } \\
\text { rutinitas sehari-hari }\end{array}$ & & $0, \overline{-}$ & & & \\
\hline TM4 & $\begin{array}{l}\text { Tujuan saya ke luar negeri adalah } \\
\text { ingin menikmati waktu luang } \\
\text { saya }\end{array}$ & & 0,872 & & & \\
\hline TM3 & $\begin{array}{l}\text { Tujuan saya ke luar negeri adalah } \\
\text { ingin beristirahat dari pekerjaan }\end{array}$ & & $\begin{array}{c}- \\
0,854\end{array}$ & & & \\
\hline TM1 & $\begin{array}{l}\text { Tujuan saya ke luar negeri adalah } \\
\text { ingin merelaksasikan tubuh }\end{array}$ & & $\begin{array}{c}- \\
0,785\end{array}$ & & & \\
\hline $\begin{array}{l}\text { Cronbach's } \\
\text { Alpha }\end{array}$ & & & 0,898 & & & \\
\hline TM10 & $\begin{array}{l}\text { Tujuan saya ke luar negeri adalah } \\
\text { ingin mempelajari tentang budaya } \\
\text { negara tujuan }\end{array}$ & & & 0,895 & & \\
\hline TM11 & $\begin{array}{l}\text { Tujuan saya ke luar negeri adalah } \\
\text { ingin mengunjungi tempat situs } \\
\text { sejarah dan budaya negara tujuan }\end{array}$ & & & 0,855 & & \\
\hline TM9 & $\begin{array}{l}\text { Tujuan saya ke luar negeri adalah } \\
\text { ingin mempelajari tentang sejarah } \\
\text { negara tujuan }\end{array}$ & & & 0,837 & & \\
\hline TM14 & $\begin{array}{l}\text { Tujuan saya ke luar negeri adalah } \\
\text { ingin mempelajari hal baru }\end{array}$ & & & 0,547 & & \\
\hline $\begin{array}{l}\text { Cronbach's } \\
\text { Alpha }\end{array}$ & & & & $\mathbf{0 , 8 7 4}$ & & \\
\hline TM19 & $\begin{array}{l}\text { Tujuan saya ke luar negeri adalah } \\
\text { ingin memuaskan rasa penasaran } \\
\text { saya }\end{array}$ & & & & 0,853 & \\
\hline TM20 & $\begin{array}{l}\text { Tujuan saya ke luar negeri adalah } \\
\text { ingin mencari hal baru }\end{array}$ & & & & 0,793 & \\
\hline TM21 & $\begin{array}{l}\text { Tujuan saya ke luar negeri adalah } \\
\text { ingin mengeksplorasi gaya hidup } \\
\text { yang berbeda }\end{array}$ & & & & 0,67 & \\
\hline $\begin{array}{l}\text { Cronbach's } \\
\text { Alpha }\end{array}$ & & & & & 0,74 & \\
\hline TM12 & $\begin{array}{l}\text { Tujuan saya ke luar negeri adalah } \\
\text { ingin memenuhi kewajiban } \\
\text { pekerjaan saya }\end{array}$ & & & & & 0,93 \\
\hline TM13 & $\begin{array}{l}\text { Tujuan saya ke luar negeri adalah } \\
\text { ingin menghadiri workshop / sesi } \\
\text { pelatihan kantor }\end{array}$ & & & & & 0,782 \\
\hline
\end{tabular}




\begin{tabular}{cc}
$\begin{array}{c}\text { Cronbach's } \\
\text { Alpha }\end{array}$ & $\mathbf{0 , 7 5 7}$ \\
\hline
\end{tabular}

Sumber: Data diolah peneliti (2020)

Dari dua puluh satu pernyataan kuesioner, variabel motivasi perjalanan tersisa sembilan belas pernyataan yang dapat membentuk faktor atau dimensi pernyataan yang lainnya dieliminasi karena adanya cross-factor, hasil faktor analisis ini membentuk lima faktor dimensi.

\section{Citra Destinasi}

\section{Tabel 4}

Faktor Analisis Citra Destinasi

\begin{tabular}{|c|c|c|c|c|c|}
\hline \multirow{2}{*}{ Nama } & \multirow{2}{*}{ Pernyataan } & \multicolumn{4}{|c|}{ Factor Loading } \\
\hline & & 1 & 2 & 3 & 4 \\
\hline DI9 & $\begin{array}{l}\text { Berkunjung ke luar negeri karena } \\
\text { memiliki iklim yang baik }\end{array}$ & 0,791 & & & \\
\hline DI11 & $\begin{array}{l}\text { Berkunjung ke luar negeri } \\
\text { memungkinkan kebutuhan saya terpenuhi }\end{array}$ & 0,762 & & & \\
\hline DI10 & $\begin{array}{l}\text { Berkunjung ke luar negeri karena } \\
\text { menawarkan akomodasi yang baik }\end{array}$ & 0,748 & & & \\
\hline DI7 & $\begin{array}{l}\text { Berkunjung ke luar negeri karena } \\
\text { memiliki standar kesehatan dan } \\
\text { kebersihan }\end{array}$ & 0,667 & & & \\
\hline DI1 & $\begin{array}{l}\text { Berkunjung ke luar negeri karena } \\
\text { mempunyai kualitas yang baik dalam hal } \\
\text { infrastruktur }\end{array}$ & 0,587 & & & \\
\hline DI5 & $\begin{array}{l}\text { Berkunjung ke luar negeri karena } \\
\text { menawarkan keamanan secara personal }\end{array}$ & 0,556 & & & \\
\hline DI8 & $\begin{array}{l}\text { Berkunjung ke luar negeri karena orang- } \\
\text { orang disana menarik dan ramah }\end{array}$ & 0,532 & & & \\
\hline $\begin{array}{c}\text { Cronbach's } \\
\text { Alpha }\end{array}$ & & $\mathbf{0 , 8 7 9}$ & & & \\
\hline DI16 & $\begin{array}{l}\text { Berkunjung ke luar negeri membuat saya } \\
\text { merasa rendah hati }\end{array}$ & & 0,836 & & \\
\hline DI15 & $\begin{array}{l}\text { Berkunjung ke luar negeri mendorong } \\
\text { saya untuk bertindak dengan penuh kasih }\end{array}$ & & 0,812 & & \\
\hline DI12 & $\begin{array}{l}\text { Berkunjung ke luar negeri membuat saya } \\
\text { penuh dengan rasa emosional }\end{array}$ & & 0,723 & & \\
\hline DI14 & $\begin{array}{l}\text { Berkunjung ke luar negeri membuat saya } \\
\text { merasa termotivasi untuk melakukan } \\
\text { sesuatu }\end{array}$ & & 0,639 & & \\
\hline DI13 & $\begin{array}{l}\text { Berkunjung ke luar negeri membuat saya } \\
\text { merasa terikat pada suatu destinasi wisata }\end{array}$ & & 0,601 & & \\
\hline $\begin{array}{l}\text { Cronbach's } \\
\text { Alpha }\end{array}$ & & & 0,816 & & \\
\hline DI18 & $\begin{array}{l}\text { Berkunjung ke luar negeri merupakan } \\
\text { liburan yang cocok bagi saya }\end{array}$ & & & $\begin{array}{c}- \\
0,804 \\
\end{array}$ & \\
\hline DI20 & $\begin{array}{l}\text { Berkunjung ke luar negeri adalah hadiah } \\
\text { terbaik yang bisa saya tawarkan sendiri }\end{array}$ & & & $\begin{array}{c}- \\
0,775\end{array}$ & \\
\hline DI17 & Saya bermimpi untuk berlibur ke luar & & & - & \\
\hline
\end{tabular}




\begin{tabular}{|c|c|c|}
\hline & negeri & 0,741 \\
\hline DI19 & $\begin{array}{l}\text { Berkunjung ke luar negeri membantu } \\
\text { meningkatkan pengetahuan saya (mis. } \\
\text { sejarah, geografi, filsafat) }\end{array}$ & $\begin{array}{c}- \\
0,555\end{array}$ \\
\hline $\begin{array}{c}\text { Cronbach's } \\
\text { Alpha }\end{array}$ & & 0,78 \\
\hline DI4 & $\begin{array}{l}\text { Berkunjung ke luar negeri karena } \\
\text { menawarkan atraksi budaya yang } \\
\text { menarik }\end{array}$ & $\begin{array}{c}- \\
0,782\end{array}$ \\
\hline DI2 & $\begin{array}{l}\text { Berkunjung ke luar negeri karena } \\
\text { mempunyai pemandangan dan wisata } \\
\text { alam yang indah }\end{array}$ & 0,698 \\
\hline DI3 & $\begin{array}{l}\text { Berkunjung ke luar negeri karena } \\
\text { menawarkan makanan lokal yang } \\
\text { menarik }\end{array}$ & $-\overline{6}$ \\
\hline DI6 & $\begin{array}{l}\text { Berkunjung ke luar negeri karena } \\
\text { memiliki objek wisata sejarah yang } \\
\text { menarik }\end{array}$ & $\overline{-}-$ \\
\hline $\begin{array}{c}\text { Cronbach's } \\
\text { Alpha } \\
\end{array}$ & & 0,812 \\
\hline
\end{tabular}

Sumber: Data diolah peneliti (2020)

Dari dua puluh pernyataan kuesioner, semua pernyataan variabel citra destinasi dapat membentuk faktor atau dimensi. Tidak ada pernyataan yang dieliminasi karena tidak ada cross-factor.

\section{Niat Berkunjung}

\section{Tabel 5}

Faktor Analisis Niat Berkunjung

\begin{tabular}{clc}
\hline Nama & \multicolumn{1}{c}{ Pernyataan } & $\begin{array}{c}\text { Factor } \\
\text { Loading }\end{array}$ \\
\cline { 2 - 3 } $\mathbf{V 2}$ & $\begin{array}{l}\text { Saya akan memilih luar negeri sebagai tujuan dari liburan } \\
\text { saya berikutnya }\end{array}$ & $\mathbf{1}$ \\
\hline $\mathbf{V 1}$ & Saya berniat ke luar negeri dalam waktu dekat & 0,907 \\
\hline V3 & $\begin{array}{l}\text { Saya lebih suka mengunjungi luar negeri daripada tujuan } \\
\text { serupa lainnya di dalam negeri }\end{array}$ & 0,876 \\
\hline $\begin{array}{c}\text { Cronbach's } \\
\text { Alpha }\end{array}$ & & 0,811 \\
\hline
\end{tabular}

Sumber: Data diolah peneliti (2020)

Dari tiga pernyataan kuesioner, variabel niat berkunjung semua pernyataan dapat difaktorkan dan tidak ada penyataan yang dieliminasi. Hasil dari perhitungan variabel visit intention membentuk satu factor loading dengan cronbach's alpha sebesar 0,819 .

\section{B. Analisis Faktor Konfirmatori}

\section{Fit Model SEM}

Hasil dari pengujian fit model ini P sebesar 0,053 CMIN/DF sebesar 1,178 TLI sebesar 0,983 CFI sebesar 0,985 dan RMSEA sebesar 0,030. Berdasarkan 
hasil dari empat alat ukur (P, CMIN/DF, TLI, CFI, dan RMSEA) semua menunjukkan angka yang baik sesuai kriteria indeks, yang mengindikasikan bahwa model sudah fit dengan data yang ada.

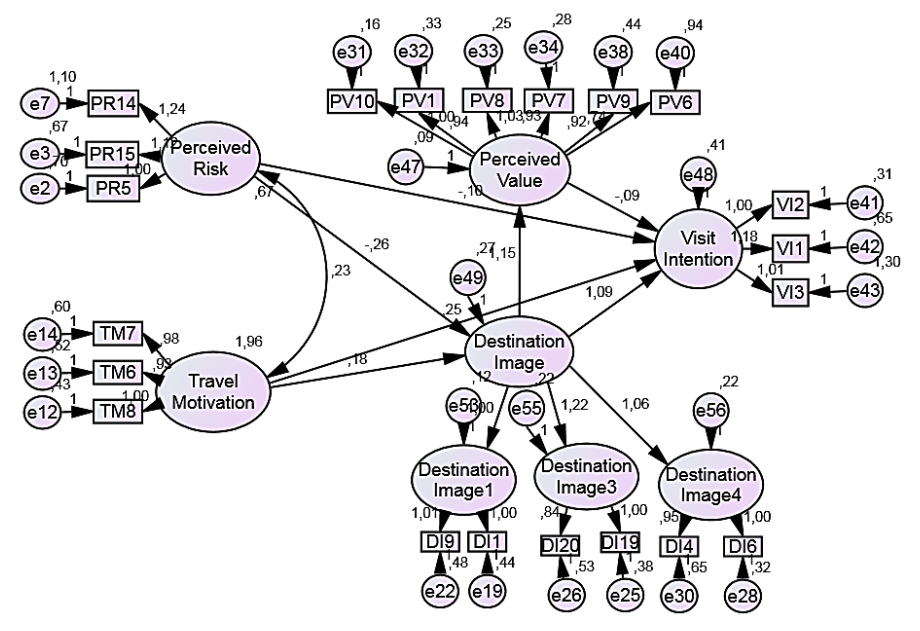

\section{Gambar 2 \\ Fit Model SEM}

Sumber: data diolah peneliti (2020)

Tabel 6

Fit Model AMOS

\begin{tabular}{lccc}
\hline Indeks & Cut Off Value & Hasil & Evaluasi Model \\
\hline $\mathbf{P}$ & $\geq 0.05$ & 0,053 & Fitted \\
\hline CMIN/DF & $\leq 2.00$ & 1,178 & Fitted \\
\hline TLI & $\geq 0.95$ & 0,983 & Fitted \\
\hline CFI & $\geq 0.95$ & 0,985 & Fitted \\
\hline RMSEA & $\leq 0.08$ & 0,030 & Fitted \\
\hline
\end{tabular}

\section{Tabel 7}

\section{Pernyataan Indikator Fit Model}

\begin{tabular}{|c|c|}
\hline Item & Pernyataan Perceived Risk \\
\hline PR14 & $\begin{array}{l}\text { Saya merasa bahwa saya tidak akan menerima kepuasan pribadi yang cukup } \\
\text { dari liburan ke luar negeri }\end{array}$ \\
\hline PR15 & Bepergian ke luar negeri tidak akan cocok dengan image saya \\
\hline PR5 & Bepergian ke luar negeri akan membuang-buang waktu saya \\
\hline Item & Pernyataan Travel Motivation \\
\hline TM7 & $\begin{array}{l}\text { Tujuan saya ke luar negeri adalah ingin mengunjungi destinasi wisata yang } \\
\text { akan membuat teman-teman saya kagum terhadap saya }\end{array}$ \\
\hline TM6 & Tujuan saya ke luar negeri adalah ingin menjadi terkenal \\
\hline TM8 & Saya ingin membuat orang-orang hormat kepada saya \\
\hline Item & Pernyataan Perceived Value \\
\hline PV10 & Saya merasakan manfaat perjalanan sesuai dengan harga yang saya bayarkan \\
\hline PV1 & Objek wisata di luar negeri memberikan kesan yang baik bagi saya \\
\hline PV8 & $\begin{array}{l}\text { Harga yang saya bayar untuk mendapatkan objek wisata yang menyenangkan di } \\
\text { luar negeri cukup wajar }\end{array}$ \\
\hline
\end{tabular}




\begin{tabular}{ll}
\hline PV7 & $\begin{array}{l}\text { Saya mendapatkan layanan yang setimpal dengan uang yang sudah saya } \\
\text { keluarkan di objek wisata yang saya kunjungi }\end{array}$ \\
\hline PV9 & $\begin{array}{l}\text { Saya mengunjungi objek wisata sesuai dengan harga yang saya bayarkan pada } \\
\text { paket wisata }\end{array}$ \\
\hline PV6 & $\begin{array}{l}\text { Saya mendapatkan pengalaman berharga di luar negeri dan saya akan } \\
\text { menceritakannya }\end{array}$ \\
\hline Item & \multicolumn{1}{c}{ Pernyataan Destination Image } \\
\hline DI9 & Berkunjung ke luar negeri karena memiliki iklim yang baik \\
\hline DI1 & $\begin{array}{l}\text { Berkunjung ke luar negeri karena mempunyai kualitas yang baik dalam hal } \\
\text { infrastruktur }\end{array}$ \\
\hline DI18 & Berkunjung ke luar negeri merupakan liburan yang cocok bagi saya \\
\hline DI20 & $\begin{array}{l}\text { Berkunjung ke luar negeri adalah hadiah terbaik yang bisa saya tawarkan } \\
\text { sendiri }\end{array}$ \\
\hline DI19 & $\begin{array}{l}\text { Berkunjung ke luar negeri membantu meningkatkan pengetahuan saya (mis. } \\
\text { sejarah, geografi, filsafat) }\end{array}$ \\
\hline DI4 & Berkunjung ke luar negeri karena menawarkan atraksi budaya yang menarik \\
\hline DI6 & Berkunjung ke luar negeri karena memiliki objek wisata sejarah yang menarik \\
\hline Item & \multicolumn{1}{c}{ Pernyataan Visit Intention } \\
\hline VI1 & Saya berniat ke luar negeri dalam waktu dekat \\
\hline VI2 & Saya akan memilih luar negeri sebagai tujuan dari liburan saya berikutnya \\
\hline VI3 & $\begin{array}{l}\text { Saya lebih suka mengunjungi luar negeri daripada tujuan serupa lainnya di } \\
\text { dalam negeri }\end{array}$ \\
\hline
\end{tabular}

\section{Pengujian Hipotesis}

Tabel 8

Estimasi Parameter Regression Weight

\begin{tabular}{|c|c|c|c|c|c|c|c|c|}
\hline $\mathrm{H} 1$ & Perceived risk & $\rightarrow$ & $\begin{array}{l}\text { Destination } \\
\text { image }\end{array}$ & $\begin{array}{c}- \\
3,819\end{array}$ & $* * *$ & Ditolak & 0,357 & Lemah \\
\hline $\mathrm{H} 2$ & $\begin{array}{l}\text { Travel } \\
\text { motivation }\end{array}$ & $\rightarrow$ & $\begin{array}{l}\text { Destination } \\
\text { image }\end{array}$ & 4,986 & $* * *$ & Diterima & 0,428 & Kuat \\
\hline $\mathrm{H} 3$ & Perceived risk & $\rightarrow$ & Visit intention & $\begin{array}{c}- \\
1,091\end{array}$ & 0,275 & Ditolak & $\begin{array}{c}- \\
0,288\end{array}$ & Lemah \\
\hline $\mathrm{H} 4$ & $\begin{array}{l}\text { Destination } \\
\text { image }\end{array}$ & $\rightarrow$ & $\begin{array}{l}\text { Perceived } \\
\text { value }\end{array}$ & 8,627 & $* * *$ & Diterima & 0,916 & Kuat \\
\hline H5 & $\begin{array}{l}\text { Travel } \\
\text { motivation }\end{array}$ & $\rightarrow$ & Visit intention & 4,679 & $* * *$ & Diterima & 0,585 & Kuat \\
\hline H6 & $\begin{array}{l}\text { Perceived } \\
\text { value }\end{array}$ & $\rightarrow$ & Visit intention & $\begin{array}{c}- \\
0,216\end{array}$ & 0,829 & Ditolak & $\overline{-}, 063$ & Lemah \\
\hline $\mathrm{H} 7$ & $\begin{array}{l}\text { Destination } \\
\text { image }\end{array}$ & $\rightarrow$ & Visit intention & 2,006 & 0,045 & Diterima & 0,579 & Kuat \\
\hline
\end{tabular}

****Tidak dapat bertahan dalam analisis SEM $(<0.001)$

Sumber: Data diolah oleh peneliti (2020)

Berdasarkan tabel 8 maka dapat dilakukan pengujian hipotesis dalam penelitian ini, yaitu sebagai berikut:

a) Variabel perceived risk memiliki nilai C.R (Critical Ratio) sebesar -3,819 yang berarti lebih kecil dari 2.00, maka perceived risk dinyatakan berpengaruh negatif dan tidak signifikan terhadap destination image dan memiliki pengaruh yang lemah dengan nilai standardized total effects sebesar -0,357. Dengan demikian 
hipotesis pertama yang menyatakan bahwa perceived risk berpengaruh positif dan signifikan terhadap destination image ditolak.

b) Variabel travel motivation memiliki nilai C.R (Critical Ratio) sebesar 4,986 yang berarti lebih besar dari 2.00, maka travel motivation dinyatakan berpengaruh positif dan signifikan terhadap destination image dan memiliki pengaruh yang kuat dengan nilai standardized total effects sebesar 0.428 . Dengan demikian hipotesis kedua yang menyatakan bahwa travel motivation berpengaruh positif dan signifikan terhadap destination image diterima.

c) Variabel perceived risk memiliki nilai C.R (Critical Ratio) sebesar -1,091 yang berarti lebih kecil dari 2.00, maka perceived risk dinyatakan berpengaruh negatif dan tidak signifikan terhadap visit intention dan memiliki pengaruh yang lemah dengan nilai standardized total effects sebesar -0.288. Dengan demikian hipotesis ketiga yang menyatakan bahwa perceived risk berpengaruh positif dan signifikan terhadap visit intention ditolak.

d) Variabel destination image memiliki nilai C.R (Critical Ratio) sebesar 8,627 yang berarti lebih besar dari 2.00, maka destination image dinyatakan berpengaruh positif dan signifikan terhadap perceived value dan memiliki pengaruh yang kuat dengan nilai standardized total effects sebesar 0.916. Dengan demikian hipotesis keempat yang menyatakan bahwa destination image berpengaruh positif dan signifikan terhadap perceived value diterima.

e) Variabel travel motivation memiliki nilai C.R (Critical Ratio) sebesar 4,679 yang berarti lebih besar dari 2.00, maka travel motivation dinyatakan berpengaruh positif dan tidak signifikan terhadap visit intention dan memiliki pengaruh yang kuat dengan nilai standardized total effects sebesar 0.585 . Dengan demikian hipotesis kelima yang menyatakan bahwa travel motivation berpengaruh positif dan signifikan terhadap visit intention diterima.

f) Variabel perceived value memiliki nilai C.R (Critical Ratio) sebesar -0,216 yang berarti lebih kecil dari 2.00, maka perceived value dinyatakan berpengaruh negatif dan tidak signifikan terhadap visit intention dan memiliki pengaruh yang lemah dengan nilai standardized total effects sebesar -0.063. Dengan demikian hipotesis keenam yang menyatakan bahwa perceived value berpengaruh positif dan signifikan terhadap visit intention ditolak.

g) Variabel destination image memiliki nilai C.R (Critical Ratio) sebesar 2,006 yang berarti lebih besar dari 2.00, maka destination image dinyatakan berpengaruh positif dan signifikan terhadap visit intention dan memiliki pengaruh yang kuat dengan nilai standardized total effects sebesar 0.579 . Dengan demikian hipotesis ketujuh yang menyatakan bahwa destination image berpengaruh positif dan signifikan terhadap visit intention diterima.

\section{Kesimpulan}

Dalam melakukan perjalanan ke luar negeri pasti akan menghadapi risiko-risiko yang ada, salah satunya masih adanya kasus positif covid-19 yang signifikan di negara 
yang akan dituju membuat keputusan untuk melakukan perjalanan ditunda atau dibatalkan guna menghindari hal-hal yang tidak diinginkan. Melakukan perjalanan ke luar negeri akan menawarkan objek wisata yang belum tentu ditawarkan di dalam negeri, responden dalam penelitian ini menyatakan di luar negeri mempunyai infrastruktur, akomodasi dan iklim yang belum bisa dirasakan jika berada di dalam negeri. Kemudian image luar negeri yang saat ini lebih baik dan lebih menarik untuk dikunjungi.

Saat pandemi covid-19 seperti sekarang ini nilai/harga yang didapat oleh calon wisatawan akan lebih terjangkau dibanding sebelumnya yang kemudian akan berdampak pada peningkatan wisatawan dan wisatawan menganggap uang yang dikeluarkan disaat pandemi ini sangat setimpal dengan apa yang mereka dapatkan pada paket wisata tersebut. Motivasi dari responden untuk melakukan perjalanan ke luar negeri adalah ingin merelaksasikan tubuh atau yang dibutuhkan adalah refreshment dari kegiatan yang saat ini sudah monoton dan membutuhkan sekali untuk berwisata ke luar negeri. Sebanyak 40,3\% responden setuju memilih luar negeri sebagai destinasi pilihan berikutnya dan sebanyak $25 \%$ responden setuju ingin melakukan perjalannya dalam waktu dekat. Ini berarti masyarakat menginginkan untuk melakukan perjalanan ke luar negeri, tinggal bagaimana untuk meminimalisir risiko-risiko yang ada pada saat melakukan perjalanan ke luar negeri. 


\section{BIBLIOGRAFI}

Carla, Siane, Andajani, Erna, \& Rahayu, Siti. (2017). Effect of destination image, perceived quality, perceived value to satisfaction and revisit intention in tanjung benoa Bali. Journal Economics \& Business Atmajaya Indonesia, 1(1), 34-42. Google Scholar

Cheng, Yi Sung, Kuo, Nien Te, Chang, Kuo Chien, \& Chen, Chien Hsu. (2019). How a tour guide interpretation service creates intention to revisit for tourists from mainland China: the mediating effect of perceived value. Journal of China Tourism Research, 15(1), 84-104. Google Scholar

Chew, Elaine Yin Teng, \& Jahari, Siti Aqilah. (2014). Destination image as a mediator between perceived risks and revisit intention: A case of post-disaster Japan. Tourism Management, 40, 382-393. Google Scholar

Hashim, NAAN, Noor, Mohd Asyraf Mohd, Awang, Zaimatul, Aziz, Roslizawati Che, \& Yusoff, Abdullah Muhamed. (2018). The Influence of Tourist Perceived Risk towards Travel Intention: A Conceptual Paper. International Journal of Academic Research in Business and Social Sciences, 8(16), 92-102. Google Scholar

Herlinda, W. D. (2020). Apindo: Selama Pandemi, Industri Pariwisata Rugi Rp21 Triliun! Retrieved from https://ekonomi.bisnis.com/read/20200426/12/1232875/apindo-selama-pandemiindustri-pariwisata-rugi-rp21-triliun

Khan, Mohammad Jamal, Chelliah, Shankar, \& Ahmed, Sahrish. (2017). Factors influencing destination image and visit intention among young women travellers: role of travel motivation, perceived risks, and travel constraints. Asia Pacific Journal of Tourism Research, 22(11), 1139-1155. Google Scholar

Lloveras, S., Rodriguez-Morales, A. J., \& Schlagenhauf, P. (2020). The next big threat to global health? 2019 novel coronavirus (2019-nCoV): What advice can we give to travellers? - Interim recommendations January 2020, from the Latin-American society for Travel Medicine (SLAMVI). Travel Medicine and Infectious Disease, 33.

Nassar, Mohamed A., Mostafa, Mohamed M., \& Reisinger, Yvette. (2015). Factors influencing travel to Islamic destinations: an empirical analysis of Kuwaiti nationals. International Journal of Culture, Tourism and Hospitality Research. Google Scholar

Ridhoo Maulaa, M. (2020). Data Google: 17 Persen Wisatawan Indonesia Ingin Lakukan Perjalanan ke Luar Negeri 3 Bulan ke Depan. Retrieved from https://www.pikiran-rakyat.com/nasional/pr-01398062/data-google-17-persenwisatawan-indonesia-ingin-lakukan-perjalanan-ke-luar-negeri-3-bulan-ke-depan

Sirait, J. (2020). Pariwisata "Inbound" versus "Outbound." Retrieved from 
https://news.detik.com/kolom/d-4886761/pariwisata-inbound-versus-outbound

Soliman, Mohammad. (2021). Extending the theory of planned behavior to predict tourism destination revisit intention. International Journal of Hospitality \& Tourism Administration, 22(5), 524-549. Google Scholar

Suwarduki, Puspa Ratnaningrum, Yulianto, Edy, \& Mawardi, M. Kholid. (2016). Pengaruh electronic word of mouth terhadap citra destinasi serta dampaknya pada minat dan keputusan berkunjung (survei pada followers aktif akun instagram indtravel yang telah mengunjungi destinasi wisata di Indonesia). Jurnal Administrasi Bisnis, 37(2), 1-10. Google Scholar

Tamtomo, A. B. (2020). INFOGRAFIK: Timeline Wabah Virus Corona. Retrieved from https://www.kompas.com/tren/read/2020/03/13/070400265/infografik--timelinewabah-virus-corona

Yacob, Syahmardi, Johannes, Johannes, \& Qomariyah, Nor. (2019). Visiting Intention: A Perspective of Destination Attractiveness and Image in Indonesia Rural Tourism. Sriwijaya International Journal of Dynamic Economics and Business, 3(2), 122-133. Google Scholar

\section{Copyright holder:}

Afif Khairi, Usep Suhud, Osly Usman (2022)

First publication right:

Syntax Literate: Jurnal Ilmiah Indonesia

\section{This article is licensed under:}

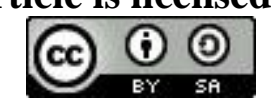

